\title{
Variation in leaf structure of the invasive Madeira vine (Anredera cordifolia, Basellaceae) at different light levels
}

\author{
Richard L. Boyne ${ }^{\mathrm{A}, \mathrm{C}}$, Olusegun O. Osunkoya ${ }^{\mathrm{B}}$ and Tanya Scharaschkin ${ }^{\mathrm{A}}$

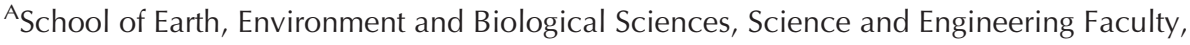 \\ Queensland University of Technology, Brisbane, Qld 4001, Australia. \\ ${ }^{B}$ Department of Agriculture, Fisheries and Forestries, Biosecurity Queensland, Ecosciences Precinct, \\ GPO Box 267, Brisbane, Qld 4001, Australia. \\ ${ }^{\mathrm{C}}$ Corresponding author. Email: rboyne@bigpond.com
}

\begin{abstract}
Madeira vine (Anredera cordifolia (Ten.) Steenis) is a climber in the angiosperm family Basellaceae. It is native to South America and has naturalised in Australia. It is regarded as a serious environmental weed because of the structural damage it causes to native vegetation. The present study, for the first time, documents anatomical and morphological traits of the leaves of $A$. cordifolia and considers their implications for its ecology and physiology. Plants were grown under three different light levels, and anatomical and morphological leaf characters were compared among light levels, among cohorts, and with documented traits of the related species, Basella alba L. Stomata were present on both the adaxial and abaxial sides of the leaf, with significantly more stomata on the abaxial side and under high light. This may account for the ability of this species to fix large amounts of carbon and rapidly respond to light gaps. The leaves had very narrow veins and no sclerenchyma, suggesting a low construction cost that is associated with invasive plants. There was no significant difference in any of the traits among different cohorts, which agrees with the claim that $A$. cordifolia primarily propagates vegetatively. The anatomy and morphology of $A$. cordifolia was similar to that of $B$. alba.
\end{abstract}

Additional keywords: anatomy, ecophysiology, phenotypic plasticity, weed.

Received 23 March 2013, accepted 9 June 2013, published online 18 July 2013

\section{Introduction}

Anredera cordifolia (Ten.) Steenis is a vigorous climbing plant native to the central and southern parts of South America (Eriksson 2007). It belongs to the family Basellaceae, a family of 19 accepted species in four genera (The Plant List 2010). Most Basellaceae are succulent climbers from the tropics and subtropics (Eriksson 2007). A well known species is the edible Basella alba L. (syn. B. rubra L.), which is thought to be native to Africa or Asia (Eriksson 2007). Anredera cordifolia has been in Australia since the 19th century (Bailey 1883), and is now regarded as an environmental weed (Vivian-Smith et al. 2007) and a weed of national significance (Australian Weeds Committee 2012). It invades a wide range of habitats including sand dunes, rainforests, sclerophyll forests, riparian zones and rock outcrops (Vivian-Smith et al. 2007). It was ranked 5th by invasiveness of 200 naturalised plants in south-eastern Queensland (Batianoff and Butler 2002) and 4th by estimated impact from among 66 invasive plant species in the same region (Batianoff and Butler 2003). In New South Wales, it is considered to have the worst impact on biodiversity (Downey et al. 2010). As with many other invasive or weedy climbers, $A$. cordifolia smothers and inhibits regeneration of native vegetation (VivianSmith et al. 2007; Fig. 1).

Anredera cordifolia has both subterranean and aerial tubers. The latter grow from leaf nodes, easily detach from the parent plant and can lie dormant for some time on the ground before sprouting (Floyd 1985; Blood 2002; Vivian-Smith et al. 2007). This may be the primary method of dispersal and reproduction because it rarely produces viable seeds (Vivian-Smith et al. 2007). The combined weight of a large number of aerial tubers could contribute to the physical damage inflicted on host plants (Vivian-Smith et al. 2007). Anredera cordifolia grows poorly under low light (Osunkoya et al. 2010a) and, consequently, tends to occur at the edges of vegetated areas or in light gaps after a disturbance (Floyd 1985; Dunphy 1991). Its invasive habit may be related to its high rate of carbon fixation in environments with high resource input (Osunkoya et al. 2010a, 2010b).

Apart from very brief descriptions (Metcalfe and Chalk 1950; Eriksson 2007), little has been published on the morphology or anatomy of $A$. cordifolia, although the related species Basella alba has been the subject of some studies (Sharma 1961; Paliwal 1965; Enriquez et al. 2000; Busuioc and Ifrim 2004; Ji and Chu 


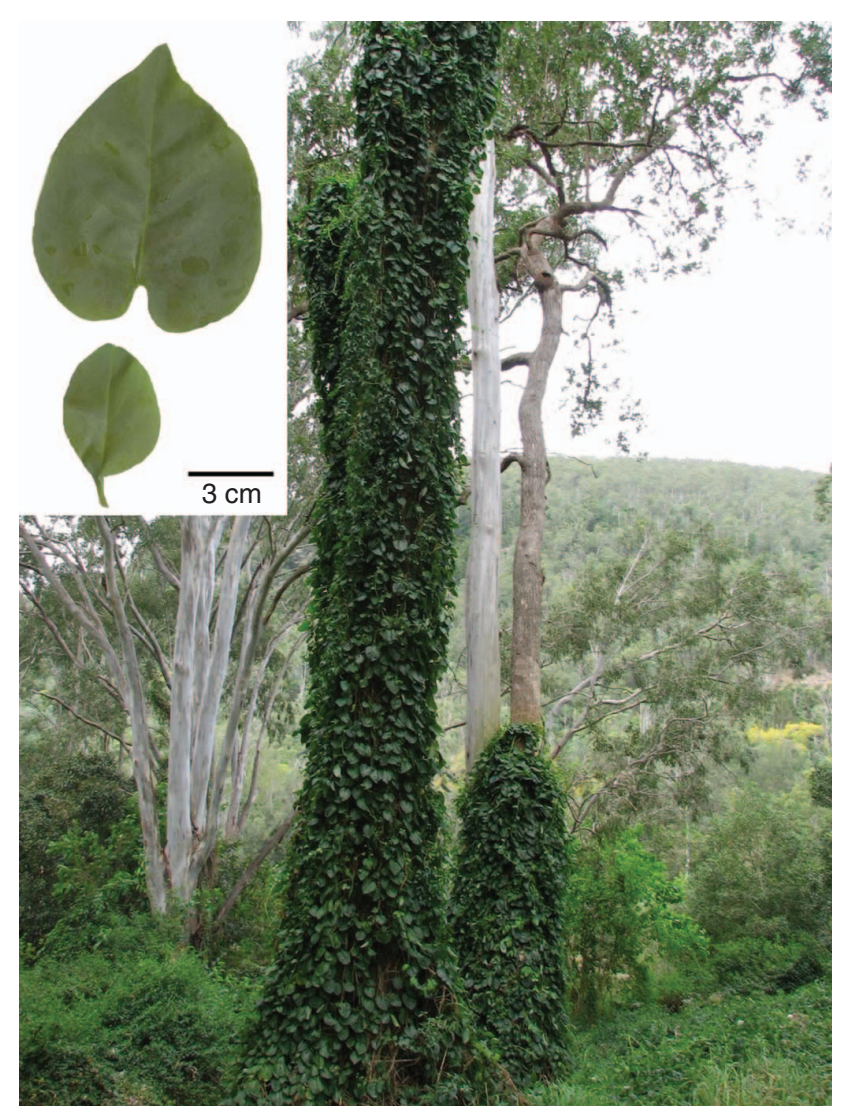

Fig. 1. Locality in Queensland, Australia, showing native vegetation infested with Anredera cordifolia. Inset, typical cordate and ovate leaves of $A$. cordifolia.

2009; Roy et al. 2010). Our study describes the leaf anatomy and morphology of $A$. cordifolia and compares it with that of $B$. alba. We also report, for the first time, changes in leaf anatomy and morphology of $A$. cordifolia in response to changes in light intensity, and discuss potential structural explanations for ecophysiological traits considered to be responsible for its invasiveness.

\section{Materials and methods}

\section{Specimen acquisition and experimental setup}

Aerial tubers were collected in July 2010 from three suburbs of Brisbane, Australia: Rocklea (27.506S, 153.014E), Yeronga (27.506S, 153.013E; 27.507S, 153.013E) and Corinda (27.55S, 152.985E). Voucher specimens of the source plants were examined by Queensland Herbarium (BRI), determined as A. cordifolia, and deposited at the Queensland University of Technology (QUT) Herbarium, Brisbane, Australia (Vouchers Boyne 41, 50-52). Sprouted tubers were placed individually in 1.3-L pots with a mixture of Australian native plant potting mix, perlite and Osmocote fertiliser for Australian natives (Scotts Australia, Sydney, NSW, Australia) in a ratio of $240: 20: 1$, respectively. Plants were grown in the greenhouse facility at QUT, under three light levels designated as low, medium and high, with photosynthetically active radiation levels of $\sim 1 \%, 29 \%$ and $44 \%$ of full sun, respectively. Twelve plants were grown under low light and 11 each under medium and high light. Plants derived from the same parent (original source of tubers) were considered to be part of the same cohort and two to three plants of each cohort were represented in each light level. Pots were regularly watered to saturation point and their positions randomised within their respective light conditions for the duration of the experiment. Fully developed, undamaged leaves were harvested in December 2010 (early summer) and February 2011 (late summer), i.e. approximately 2 and 4 months after the establishment of plants in their respective light treatments. Voucher specimens (Boyne 74-79, Boyne 89-97, Boyne 132-140, Boyne 153-161, Boyne 184-190) from this experiment have been deposited in the QUT herbarium.

\section{Leaf morphology}

Freshly harvested leaves were scanned using a flatbed scanner and leaf area was measured using ImageJ (Davidson 2010). Terminology for describing leaf morphology was based on the Kew Plant Glossary (Beentje 2010).

\section{Leaf surface anatomy}

Clear nail varnish was applied to the abaxial (lower) and adaxial (upper) surfaces of leaves and transferred to slides with clear adhesive tape (Cutler et al. 2008). These were examined under a light microscope (Nikon Eclipse 50i; Nikon, Tokyo, Japan) and images were captured with an attached Nikon DS-Fil camera head. Three views were taken of each epidermal impression (Grant and Vatnick 2004; Hoagland 2007), avoiding midribs, margins and areas close to the base and apex of the leaf. Within each view, comparisons were made with prior information on $B$. alba. The length of guard cells was measured using NISElements software (Nikon). The number of stomata and epidermal cells within each view were used to calculate the stomatal density and stomatal index (Salisbury 1928; Gupta 1961). The formula for the stomatal index is $E \times 100 /(E+S)$, where $\mathrm{E}$ is the number of epidermal cells and $\mathrm{S}$ is the number of stomata.

\section{Leaf internal anatomy}

Leaves were fixed in $70 \%$ ethanol and infiltrated and embedded in paraffin wax. Sections (15- $\mu \mathrm{m}$ thickness) were cut with a rotary microtome. Sections were placed on APES-covered slides and oven-dried overnight at $37^{\circ} \mathrm{C}$ overnight. Slides were stained by immersion in $0.5 \%$ toluidine blue $\mathrm{O}$ for $20 \mathrm{~min}$ and oven-dried (after Sakai 1973; Kiernan 1996). Paraffin was removed with two changes of xylene and coverslips were applied with distyrene, plasticiser and xylene (DPX) mountant. Three sections from each leaf were photographed following the same protocol as that for epidermal impressions. Total thickness for each section was measured and the structure of cells and tissues was compared with what has been published for $B$. alba.

\section{Data analysis}

Leaf area data came from both harvests, whereas all other data were obtained from the first harvest only. Data were summarised and analysed using Excel and SPSS (version 19; IBM, Armonk, NY, USA). As the data were not normally distributed, 
Kruskall-Wallis tests were performed using individual plants as replicates, so as to assess differences in leaf morphology and anatomy among light levels and cohorts.

\section{Results}

No significant differences were found in the data among different cohorts, so the data were combined for each light level. Data are presented as the mean \pm s.e.m. in Table 1 .

\section{Leaf morphology and area}

Leaves were petiolate and generally cordate or ovate in shape, with entire or slightly undulate margins. The leaf apex shape ranged from obtuse to slightly acute, with an apiculate or retuse tip (Fig. 1, see inset). The midrib was prominent on the abaxial surface. Secondary veins were pinnate, with the tertiary veins anastomosing towards the margin. For the first harvest, light had a significant effect on the mean leaf area, with higher values for plants grown under medium and high light than for those grown under low light. For the second harvest, there were variations in leaf area among the light treatments, but the differences were non-significant $(P>0.05$, Table 1$)$. Average leaf area was significantly lower in the second harvest than in the first $(P<0.001$, Table 1$)$.

\section{Leaf surface anatomy}

Both leaf surfaces lacked trichomes and were smooth and glabrous, more so on the abaxial surface. Stomata were generally paracytic (sensu Carpenter 2005), with two or three lateral subsidiary cells (Fig. 2). The majority of epidermal cells were irregular with sinuous anticlinal walls (Fig. $2 a, b$ ), although a few were polygonal with straight walls, particularly in areas over veins (Fig. $2 c, d$ ). Stomata were present on both leaf surfaces (amphistomaty), with the abaxial surface generally having more stomata than the adaxial (Table 1). This difference was significant for both stomatal density $(P=0.002)$ and stomatal index $(P=0.001)$ when all light levels were combined. The stomatal density and index on the abaxial surface exhibited a significant light effect $(P=0.009$ and $P=0.010$, respectively), with an apparent positive correlation with the light level (Table 1).

\section{Leaf anatomy}

The average leaf thickness was higher under high light than under the other light levels, although the difference was not statistically significant (Table 1). Some cells in the mesophyll were large and heavily pigmented, and were classified as mucilage cells by comparison with B. alba (Ji and Chu 2009; Fig. 3a). Calcium oxalate druses were observed in some mesophyll cells (Fig. $3 b$ ). The midrib seemed to lack bundle-sheath cells and mechanical elements such as sclerenchyma. The abaxial side of the midrib was composed of parenchyma cells (Fig. 3c). Veins elsewhere in the leaf were very narrow and appeared to lack bundle sheaths. Mucilage cells, druses and veins were not frequently encountered, so it could not be determined whether they varied with light level. The overall internal structure of the leaves, and parenchyma cells in particular, appeared distorted (Fig. 3).

\section{Discussion}

Our observations of the leaf morpholgy and anatomy of A. cordifolia largely conformed to what is known about B. alba. Basella alba appears to have leaf morphology similar to that of $A$. cordifolia, including a cordate leaf with an obtuse or acute apex (Eriksson 2007; Roy et al. 2010). As with A. cordifolia, B. alba is amphistomatous and has similar subsidiary cells (Sharma 1961; Paliwal 1965; Enriquez et al. 2000; Busuioc and Ifrim 2004). The mesophyll of B. alba contains mucilage cells ( $\mathrm{Ji}$ and $\mathrm{Chu} 2009$ ) and druses (Metcalfe and Chalk 1950; Busuioc and Ifrim 2004). The veins of $B$. alba are narrow, the midrib lacks mechanical elements, and there appears to be little or no differentiation between palisade and spongy mesophyll layers (Busuioc and Ifrim 2004; Ji and Chu 2009). Basella alba differs from A. cordifolia in having smaller mesophyll cells ( $\mathrm{Ji}$ and Chu 2009) and slightly larger stomata (Roy et al. 2010).

Table 1. Mean ( \pm s.e.m.) values for morphological and anatomical traits of Anredera cordifolia leaves compared across three light levels Traits that exhibited a significant $(P<0.05)$ difference among the light levels are indicated with an asterisk $(*) ; n=$ number of individual plants examined

\begin{tabular}{|c|c|c|c|c|}
\hline \multirow[t]{2}{*}{ Leaf trait } & \multicolumn{4}{|c|}{ Light level } \\
\hline & Low light & Medium light & High light & All light levels \\
\hline \multicolumn{5}{|l|}{ Area $\left(\mathrm{mm}^{2}\right)$} \\
\hline 1st harvest* & $3080.16 \pm 173.52(n=6)$ & $4189.56 \pm 269.52(n=10)$ & $3682.91 \pm 170.39(n=6)$ & $3800.80 \pm 170.39(n=22)$ \\
\hline 2nd harvest & $2050.32 \pm 91.06(n=12)$ & $1789.23 \pm 118.33(n=9)$ & $2177.00 \pm 164.82(n=11)$ & $2005.10 \pm 75.50(n=32)$ \\
\hline Both harvests & $2209.34 \pm 87.38(n=18)$ & $2526.76 \pm 142.70(n=19)$ & $2625.84 \pm 152.89(n=17)$ & $2474.97 \pm 79.67(n=54)$ \\
\hline Leaf thickness $(\mu \mathrm{m})$ & $244.73 \pm 17.38(n=3)$ & $254.24 \pm 13.83(n=6)$ & $294.51 \pm 21.90(n=4)$ & $264.43 \pm 10.38(n=13)$ \\
\hline \multicolumn{5}{|c|}{ Leaf stomatal density (number per area) } \\
\hline Adaxial & $14.03 \pm 4.57(n=4)$ & $9.35 \pm 1.67(n=9)$ & $21.04 \pm 3.80(n=6)$ & $14.03 \pm 1.82(n=19)$ \\
\hline Abaxial* & $12.86 \pm 2.71(n=4)$ & $26.49 \pm 2.73(n=9)$ & $56.10 \pm 7.61(n=6)$ & $32.97 \pm 3.52(n=19)$ \\
\hline \multicolumn{5}{|l|}{ Leaf stomatal index } \\
\hline Adaxial & $6.42 \pm 1.68(n=4)$ & $4.51 \pm 0.79(n=9)$ & $6.695 \pm 0.85(n=6)$ & $5.60 \pm 0.59(n=19)$ \\
\hline Abaxial* & $7.28 \pm 1.36(n=4)$ & $9.81 \pm 0.71(n=9)$ & $12.41 \pm 0.65(n=6)$ & $10.10 \pm 0.54(n=19)$ \\
\hline \multicolumn{5}{|l|}{ Stomatal length $(\mu \mathrm{m})$} \\
\hline Adaxial & $31.10 \pm 0.66(n=4)$ & $34.69 \pm 0.79(n=9)$ & $32.78 \pm 1.58(n=6)$ & $33.37 \pm 0.74(n=19)$ \\
\hline Abaxial & $33.45 \pm 1.75(n=3)$ & $34.66 \pm 1.10(n=8)$ & $33.96 \pm 0.98(n=6)$ & $34.20 \pm 0.69(n=17)$ \\
\hline
\end{tabular}



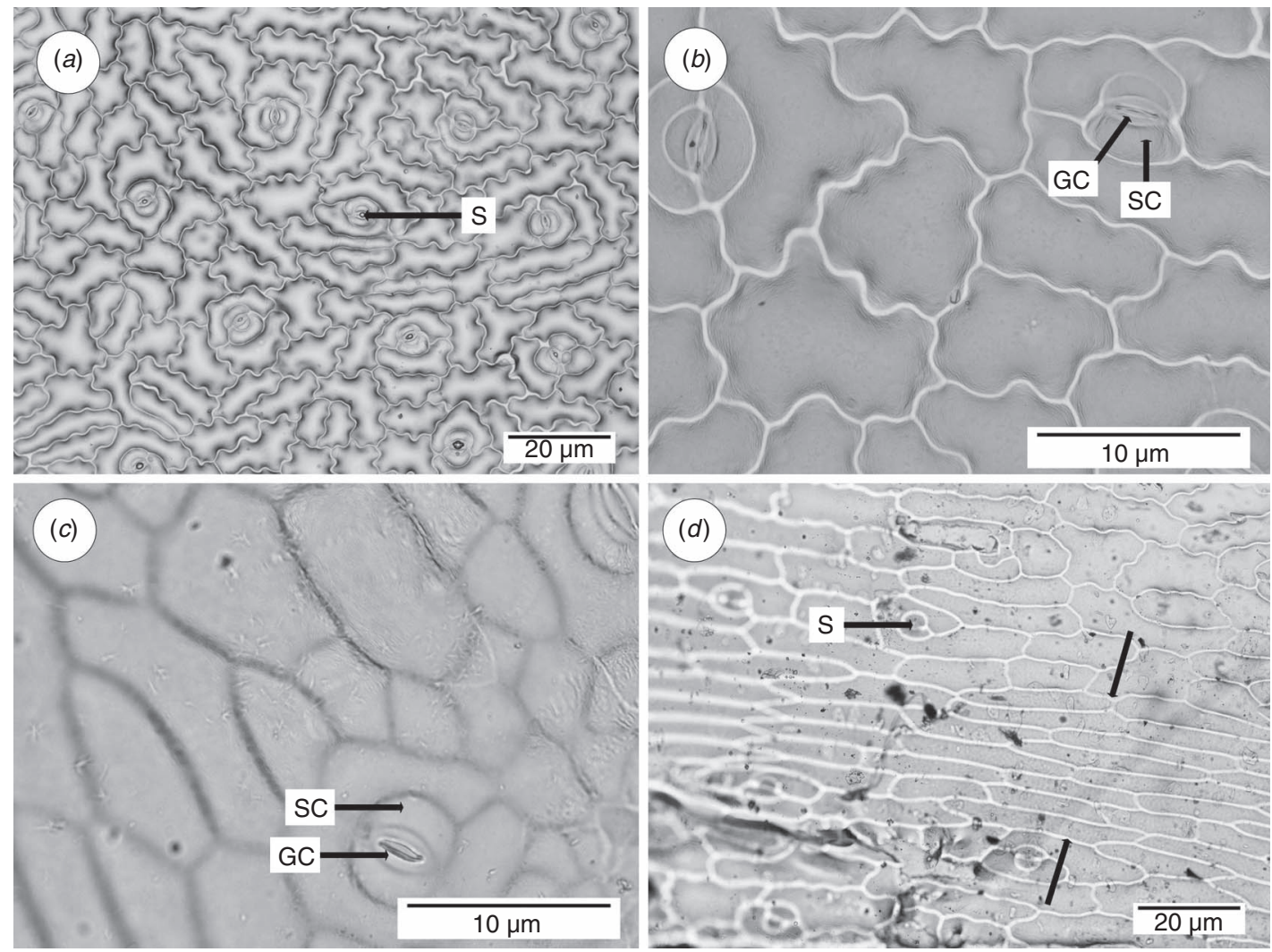

Fig. 2. Epidermal impressions of Anredera cordifolia leaves grown under different light levels. (a) Adaxial surface, high light, with various shapes of sinuouswalled epidermal cells and distribution of stomata. (b) Adaxial surface, high light, with sinuous-walled epidermal cells and details of guard and subsidiary cells. (c) Abaxial surface, medium light, with straight-walled epidermal cells. (d) Adaxial surface, low light, with a row of straight-walled epidermal cells (marked with arrows), possibly over a vein. GC, guard cell; S, stoma; SC, subsidiary cell.

Light is often cited as having an effect on leaf area, with sun leaves being typically smaller than shade leaves (Young and Smith 1980; Hart 1988; Sultan 2000; Markesteijn et al. 2007; Robinson 2007). The present study showed no such correlation. Instead, the main difference seemed to be between the two harvests in which mean leaf area decreased with time. The cause of this is unknown, but possible explanations include seasonal differences in leaf size, increased carbon allocation to tubers as the plants matured, or the second harvest may have included a greater number of immature leaves.

The greater number of abaxial stomata under high light is a previously undocumented observation for this species and family. Ecophysiological work has indicated that $A$. cordifolia exhibits a significantly higher area-based maximum photosynthesis and higher water-use efficiency under a high than a low light condition, and in comparison with many of its co-occurring exotic and native species of climber (Osunkoya et al. 2010b). Our results provided a possible structural basis for this ecophysiological response. More stomata could allow more $\mathrm{CO}_{2}$ to diffuse faster into the mesophyll (Mott et al. 1982; Woodruff et al. 2008), which would otherwise be slow for a plant with thick leaves, such as A. cordifolia. This can increase the rate of carbon fixation where light and water are not limiting (Mott et al. 1982; Smith et al. 1998), but would be inefficient under resource-stressed conditions (see Osunkoya et al. 2010b). Furthermore, amphistomaty is a characteristic of pioneer plants that grow in high light (Mott et al. 1982) such as the invasive climber kudzu, Pueraria lobata (Willd.) Ohwi (Fabaceae; Pereira-Netto et al. 1999). Thus, amphistomaty coupled with efficient vegetative dispersal across varying landscapes via the climbing habit and aerial tubers may explain the success of A. cordifolia in full-sun habitats and along riparian corridors as long as moisture availability is not limiting. Amphistomaty is also associated with $\mathrm{C}_{4}$ plants (Mott et al. 1982). However, there is so far no evidence that $A$. cordifolia is a $\mathrm{C}_{4}$ plant; however, $\mathrm{C}_{4}$ fixation is possible without anatomical specialisation (bundle sheaths), as has been observed in Bienertia cycloptera Bunge (Amaranthaceae; Voznesenskaya et al. 2002). More research is needed across related species in Basellaceae on leaf anatomy and morphology, including spatio-temporal changes in stomatal abundance and distribution, to explore further the ecological and/ or evolutionary advantage of amphistomaty, especially its relationships to invasiveness.

The very narrow vascular bundles and lack of sclerenchyma in A. cordifolia suggest that the leaves are supported primarily by turgor pressure. It was also observed that they became very thin and limp after being fixed or dried. This may explain the relatively low construction cost of $A$. cordifolia leaves relative 

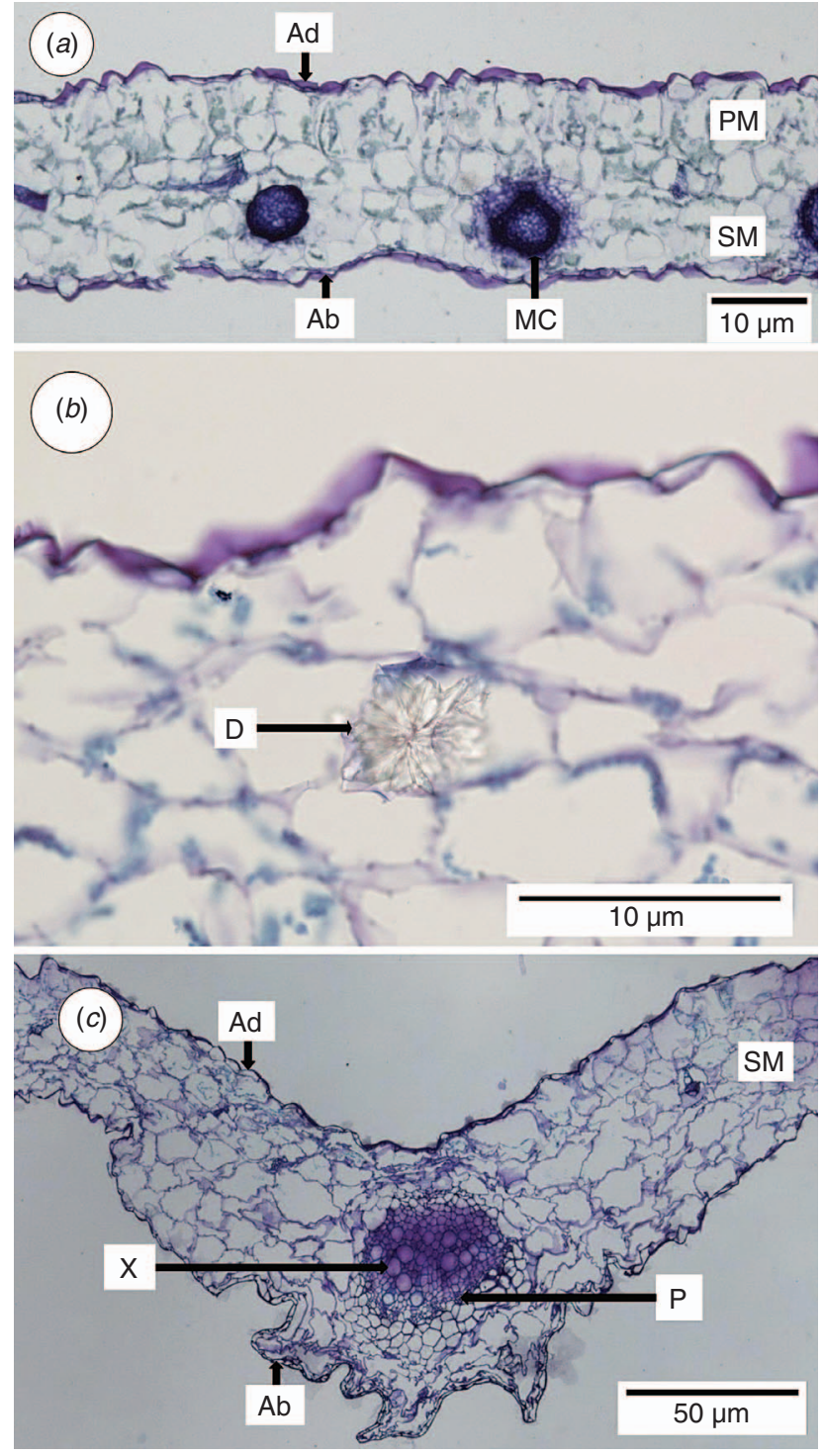

Fig. 3. Sections of Anredera cordifolia leaves grown under three light levels and stained with toluidine blue O. (a) High light, showing overall mesophyll structure and mucilage cells. (b) Medium light, showing a druse inside a mesophyll cell. (c) Medium light, showing midrib and parenchyma cells (the latter appear distorted, probably an artefact of the fixation or dehydration before wax infiltration). Ab, abaxial epidermis; Ad, adaxial epidermis; D, druse; MC, mucilage cell; P, phloem; PM, palisade mesophyll; SM, spongy mesophyll; X, xylem.

to co-occurring exotic and native climbers in Australia, and its comparatively low water-use efficiency, especially under low light (Osunkoya et al. 2010b).

\section{Conclusions}

The present study has made an important contribution to the basic knowledge regarding the morphology and anatomy of A. cordifolia and has provided possible structural explanations for ecophysiological traits considered to be responsible for its invasiveness. The vigorous growth and ability to rapidly exploit light gaps and edges in vegetation may be related to its amphistomatous leaves and the plasticity of its stomatal production. The observed lack of sclerenchyma and narrow veins in $A$. cordifolia leaves suggest a reliance on turgor pressure for support and, hence, very little carbon is invested in their construction, potentially allowing more to be allocated to growth or reproduction, such as the aerial tubers, and may also contribute to its invasiveness. The lack of significant differences between different cohorts for any of the traits measured is not surprising, because this species appears to reproduce almost entirely by vegetative propagation. Comparative studies of $A$. cordifolia with less invasive relatives, such as $B$. alba, or other members of the Anredera genus may help answer more questions about its invasiveness. Because nothing is known about the genetic variability of $A$. cordifolia in Australia, we advocate for research on the ecological genetics of this species within its native range and in novel or introduced environments.

\section{Acknowledgements}

The authors thank K. Boyne for assistance with sample collection, staff and students at QUT, including Mark Crase, Peraj Karbaschi, Melody Fabillo and Helen O'Connor, for assistance with different aspects of this study, I. Williamson (QUT) for advice on statistical analysis and the staff at the Queensland Herbarium (BRI) for identifying voucher specimens.

\section{References}

Australian Weeds Committee (2012) 'Madeira vine Anredera cordifolia.' (Weeds of National Significance: Canberra). Available at http://www. weeds.org.au/WoNS/madeiravine/ [Verified September 2012].

Bailey FM (1883) 'A synopsis of the Queensland flora: containing both the phaenogamous and cryptogamous plants.' (Government Printer: Brisbane)

Batianoff GN, Butler DW (2002) Assessment of invasive naturalized plants in south-east Queensland. Plant Protection Quarterly 17, 27-34.

Batianoff GN, Butler DW (2003) Impact assessment and analysis of sixty-six priority invasive weeds in south-east Queensland. Plant Protection Quarterly 18, 11-17.

Beentje H (2010) 'The Kew plant glossary.' (Kew Publishing: London)

Blood K (2002) Weed watch warning: Madeira vine, Anredera cordifolia. Under Control 20, 10-11.

Busuioc G, Ifrim C (2004) Some histo-anatomical aspects concerning the leaf structure of Basella alba and Basella rubra. Journal of Plant Development 12, 95-99.

Carpenter KJ (2005) Stomatal architecture and evolution in basal angiosperms. American Journal of Botany 92, 1595-1615. doi:10.3732/ajb.92.10.1595

Cutler DF, Botha CEJ, Stevenson DW (2008) 'Plant anatomy: an applied approach.' (Blackwell Publishing: Malden, MA)

Davidson A (2010) 'Measuring leaf perimeter and leaf area.' (CSIRO Publishing: Melbourne). Available at http://prometheuswiki.publish. csiro.au/tiki-index.php?page=Measuring+leaf + perimeter+and+leaf + area [Verified November 2012].

Downey PO, Scanlon TJ, Hosking JR (2010) Prioritizing weed species based on their impact on biodiversity: a case study from New South Wales. Plant Protection Quarterly 25, 111-126.

Dunphy M (1991) Rainforest weeds of the big scrub. In 'Proceedings of a workshop held at the North Coast'. (Ed. P Stephen) pp. 109-115. (New South Wales National Parks and Wildlife: Lismore, NSW)

Enriquez FG, Kawada K, Matsui T (2000) Effects of storage temperature on the keeping quality of Malabar spinach (Basella alba L.). Food Preservation Science 26, 211-217. doi:10.5891/jafps.26.211

Eriksson R (2007) A synopsis of Basellaceae. Kew Bulletin 62, 297-320. 
Floyd AG (1985) Management of small rainforest areas (Part 1). National Parks Journal 29, 17-19.

Grant BW, Vatnick I (2004) 'Environmental correlates of leaf stomata density.' Teaching Issues and Experiments in Ecology. (Ecological Society of America: Washington, DC). Available at http://tiee.ecoed. net/vol/v1/experiments/stomata/stomata_description.html [Verified November 2012].

Gupta BB (1961) Correlation of tissues in leaves II. Absolute stomatal numbers. Annals of Botany 25, 71-77.

Hart JW (1988) 'Light and plant growth.' (Unwin Hyman: London)

Hoagland B (2007) 'Stomata study.' (Biol 128 Labs, Westfield State University, Westfield, MA). Available at http://biology.wsc.ma.edu/ biol128Labs/stomata-study [Verified January 2011].

Ji G-X, Chu Q-G (2009) Developmental structure and distribution of mucilage cells in Basella alba. Xibei Zhiwu Xuebao 29, 1816-1821. [in Chinese with an English abstract]

Kiernan JA (1996) Staining paraffin sections without prior removal of the wax. Biotechnic \& Histochemistry 71, 304-310. doi:10.3109/10520299609117180

Markesteijn L, Poorter L, Bongers F (2007) Light-dependent leaf trait variation in 43 tropical dry forest tree species. American Journal of Botany 94, 515-525. doi:10.3732/ajb.94.4.515

Metcalfe CR, Chalk L (1950) 'Anatomy of the dicotyledons.' (Clarendon Press: Oxford, UK)

Mott KA, Gibson AC, O'Leary JW (1982) The adaptive significance of amphistomatic leaves. Plant, Cell \& Environment 5, 455-460. doi:10.1111/1365-3040.ep11611750

Osunkoya OO, Bayliss D, Panetta FD, Vivian-Smith G (2010a) Variation in ecophysiology and carbon economy of invasive and native woody vines of riparian zones in south in south eastern Queensland. Austral Ecology 35, 636-649. doi:10.1111/j.1442-9993.2009.02071.x

Osunkoya OO, Bayliss D, Panetta FD, Vivian-Smith G (2010b) Leaf trait co-ordination in relation to construction cost, carbon gain and resourceuse efficiency in exotic invasive and native woody vine species. Annals of Botany 106, 371-380. doi:10.1093/aob/mcq119

Paliwal GS (1965) The development of stomata in Basella rubra Linn. Phytomorphology 15, 50-53.

Pereira-Netto AB, Gabrielle AC, Pinto HS (1999) Aspects of leaf anatomy of kudzu (Pueraria-lobata, Leguminosae-Faboideae) related to water and energy balance. Pesquisa Agropecuaria Brasileira 34, 1361-1365. doi:10.1590/S0100-204X1999000800006
Robinson SA (2007) Light stress. In 'Handbook of plant science'. (Ed. K Roberts) pp. 1324-1329. (John Wiley and Sons: Chichester, UK)

Roy SK, Gangopadhyay G, Mukherjee KK (2010) Is the stem twining form of Basella alba L. a naturally occurring variant? Current Science $\mathbf{9 8}$, 1370-1375.

Sakai WS (1973) Simple method for differential staining of paraffin embedded plant material using toluidine blue O. Stain Technology 48, 247-249.

Salisbury EJ (1928) On the causes and ecological significance of stomatal frequency, with special reference to the woodland flora. Philosophical Transactions of the Royal Society of London. Series B, Containing Papers of a Biological Character 216, 1-65. doi:10.1098/rstb.1928.0001

Sharma HP (1961) Contributions to the morphology and anatomy of Basella rubra Linn. Bulletin of the Botanical Society of Bengal 15, 43-48.

Smith WK, Bell DT, Shepherd KA (1998) Associations between leaf structure, orientation, and sunlight exposure in five Western Australian communities. American Journal of Botany 85, 56-63. doi: $10.2307 / 2446554$

Sultan SE (2000) Phenotypic plasticity for plant development, function and life history. Trends in Plant Science 5, 537-542. doi:10.1016/S1360-1385(00)01797-0

The Plant List (2010) Version 1. 'Basellaceae'. Available at www.theplantlist. org/browse/A/Basellaceae [Verified 8 May 2013].

Vivian-Smith G, Lawson BE, Turnbull I, Downey PO (2007) The biology of Australian weeds 46. Anredera cordifolia (Ten.) Steenis. Plant Protection Quarterly 22, 2-10.

Voznesenskaya EV, Francheschi VR, Kiirats O, Artyusheva EG, Freitag H, Edwards $\mathrm{G}$ (2002) Proof of $\mathrm{C}_{4}$ photosynthesis without Kranz anatomy in Bienertia cycloptera (Chenopodiaceae). The Plant Journal 31, 649-662. doi:10.1046/j.1365-313X.2002.01385.x

Woodruff DR, Meinzer FC, Lachebruch B, Johnson DM (2008) Coordination of leaf structure and gas exchange along a height gradient in a tall conifer. Tree Physiology 29, 261-272. doi:10.1093/treephys/tpn024

Young D, Smith WK (1980) Influence of sunlight on photosynthesis, water relations and leaf structure in the understory species Arnica cordifolia. Journal of Ecology 61, 1380-1390. doi:10.2307/1939047 